
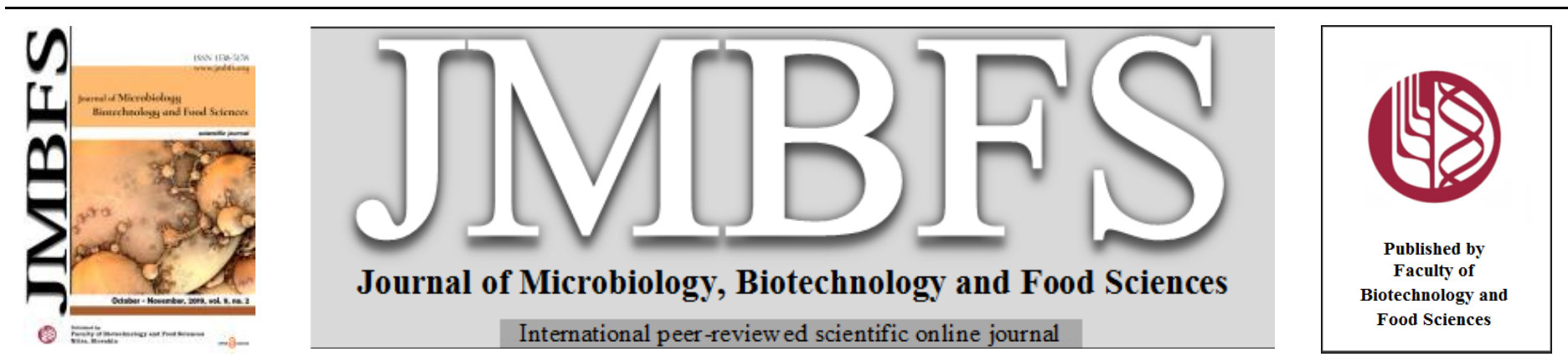

\title{
IDENTIFICATION OF VARIATIONS IN THE CODING REGION OF MYOSTATIN (MSTN) GENE OF THALLI AND PAK-KARAKUL SHEEP BREED IN PAKISTAN
}

\author{
Armughan Ahmed Wadood ${ }^{1}$, Haleema Sadia ${ }^{2}$, Lu Yangqing ${ }^{3}$, Tanveer Hussain ${ }^{4}$, Muhammad Safdar ${ }^{4}$, Qaisar Shahzad ${ }^{3}$, Kanwal \\ Ashiq ${ }^{5}$, Asad Ali ${ }^{1}$ Sana Ashiq ${ }^{6}$
}

\begin{abstract}
Address(es):
${ }^{1}$ Department of Livestock Production, University of Veterinary and Animal Sciences, Lahore, Pakistan.

${ }^{3}$ Animal Reproductive Biotechnology Institute, Guangxi University, China.

${ }^{4}$ Department of Molecular Biology, Virtual University of Pakistan.

${ }^{5}$ Faculty of Pharmaceutical Sciences, Superior University 17-km Raiwind Road Lahore, Pakistan.

${ }^{6}$ Sharif Medical and Dental College, Sharif Medical Complex Lahore, Pakistan.
\end{abstract}

${ }^{2}$ Department of Biotechnology, Balochistan University of Information Technology, Engineering and Management Sciences, Quetta-87300.

*Corresponding author: sadiahaleema377@gmail.com

doi: 10.15414/jmbfs.2019.9.2.335-337

\section{ARTICLE INFO}

Received 9. 5. 2019

Revised 24. 6. 2019

Accepted 24. 6. 2019

Published 1. 10. 2019

Regular article OPEN $\partial_{\text {ACCESS }}$

\begin{abstract}
Marker assisted selection (MAS) is a potential tool to genetically enhance the traits of economic importance in livestock production. One of the gateways to MAS is the identification of SNPs for the desired genes. The aim of the present study was to detect SNPs in myostatin (MSTN) gene which has a negative role in growth and skeletal muscle development. Therefore, polymorphisms of the exon no 1, 2 and 3 of MSTN gene were studied in Thalli $(\mathrm{n}=10)$ and Pak-karakul $(\mathrm{n}=10)$ sheep breeds. The genomic DNA was isolated and amplified by using PCR. The amplicons were purified and sequenced. After PCR all samples were sent to Singapore for $1^{\text {st }}$ base laboratory for further purification and sequencing. Sequencing analysis was done using Codon Code Aligner and MEGA 6 software's. Mutations were observed at only exon no 1 in $50 \%(5 / 10)$ Thalli sheep (heterozygous G $>\mathrm{T}=3 / 5$, synonymous $=2 / 5)$ and $20 \%(2 / 10)$ Pak-karakul sheep (only synonymous T mutations) at 3995bp. The two alleles (A and B) were found having all the three combinations of genotypes i.e. $\mathrm{AA}, \mathrm{AB}$ and $\mathrm{BB}$. Allele frequencies $(\mathrm{A}+\mathrm{B})$ were 0.2 and 0.8 in Pak-karakul and in case of Thalli it was 0.5 in each. The data from the present study suggests that SNPs in MSTN gene are present. Furthermore, scope of the present study may be enhanced to establish a marker for improved mutton production through conducting association studies at large scale.
\end{abstract}

\section{INTRODUCTION}

Myostatin (MSTN) belongs to the TGF- $\beta$ superfamily of signal transduction proteins, which demonstrates a significant role in muscular growth and lipid metabolism (An et al., 2011). It plays a major role as a adverse regulator in the development and growth of skeletal muscles. The function of MSTN gene was explored by producing the mice without MSTN gene, as mice without MSTN gene had higher muscular growth than mice having MSTN gene (Whittemore et al., 2003). Different forms of MSTN gene exist in many livestock species and each form of gene has been associated with some productive trait (Gan $\boldsymbol{e t}$ al., 2008). The polymorphism in this gene has been determined in various breeds of sheep (Zhou et al., 2008) and goat (Han et al., 2015). Ovine MSTN gene is 4991 bp in size and is present on chromosome no. 2 (Boman et al., 2009). Single Nucleotide Polymorphisms (SNPs) within the coding region of myostatin gene have been found to be associated with double muscling (Hadjipavlou $\boldsymbol{e t}$ al., 2008). Moreover the myostatin sequence analysis of double muscled European breed revealed 7 DNA sequence polymorphisms and concluded that five of them were responsible in modulating the functions of protein (Joulia-Ekaza \& Cabello, 2007). Genetic characterization of Boer goat for myostatin gene also confirmed SNPs associated with productive and reproductive traits (Zhang $\boldsymbol{e t}$ al., 2012). Strategies to improve profitability in sheep industry mainly focus on the reproductive traits (Wang and Wu, 2006; Yu L et al., 2007). However, mutations occur naturally in sheep which affect muscular growth and development. The best documented mutation for muscle development in sheep is callipyge (CLPG), which causes a postnatal muscle hypertrophy that is localized to the pelvic limbs and loin (Noelle, 2005). Similarly variations in MSTN gene has been studied by various scientists (Tay, 2004) and interestingly these are being used as a selection marker for improved muscular yield commercially (Zhang et al., 2012).
However, to our knowledge, there is no study available in the literature investigating the variations in myostatin gene of Thalli and Pak-Karakul sheep in Pakistan. Therefore, the aims of this study were to: find out the variations in myostatin gene of Thalli and Pak-Karakul sheep and design the effective breeding plans of Thalli and Pak-Karakul sheep in Pakistan for enhanced mutton production through increased growth rate.

\section{MATERIALS AND METHODS}

The data from adult male sheep of Thalli $(n=10)$ and Pak-karakul $(n=10)$ at Small Ruminants Research and Development Centre, RakhKhairewala, District Layyah, Pakistan were collected. A total of five $\mathrm{ml}$ blood sample was collected from jugular vein from each animal in $15 \mathrm{ml}$ falcon tube containing $200 \mu 1$ EDTA. Genomic DNA was extracted from whole blood samples by using modified method (Sambrook et al., 1989). The extracted genomic DNA was stored at $20^{\circ} \mathrm{C}$. Agarose Gel-electrophoresis technique was used to confirm the extracted DNA. New Primers were designed using sequence of myostatin gene available at NCBI public gene bank database (Gene ID: 443449). Primers were designed (Table 1) for amplification of Exon 1, 2 and 3 of ovine MSTN gene by online free software (Primerfox), available at website (http://www.primerfox.com/). Gradient PCR for each exon was done to find the actual annealing temperature of each primer. Initial denaturation was done at $95^{\circ} \mathrm{C}$ for $3 \mathrm{~min}$ and then cycle started at $95^{\circ} \mathrm{C}$ for $30 \mathrm{sec}$. Annealing comprised of 35 cycles, each cycle of 45 seconds at $50-60^{\circ} \mathrm{C}$ and extension was done at $72^{\circ} \mathrm{C}$ for $45 \mathrm{sec}$. Final extension was carried out at $72^{\circ} \mathrm{C}$ for $10 \mathrm{~min}$ and then amplicons were stored at $4^{\circ} \mathrm{C}$. After finding the annealing temperature $\left(52^{\circ} \mathrm{C}\right.$ and $\left.59^{\circ} \mathrm{C}\right)$ at gradient PCR, PCR was done. First initial denaturation was done at $95^{\circ} \mathrm{C}$ for $3 \mathrm{~min}$ and then cycle started at $95^{\circ} \mathrm{C}$ for $30 \mathrm{sec}$. Annealing comprised of 35 cycles, each cycle of $45 \mathrm{sec}$ at $58^{\circ} \mathrm{C}$ of exon 1,3 and $50^{\circ} \mathrm{C}$ for exon 2 . Extension was done at $72^{\circ} \mathrm{C}$ for $45 \mathrm{sec}$ and final extension was carried out at $72^{\circ} \mathrm{C}$ for $10 \mathrm{~min}$. Then amplicons were stored at $4^{\circ} \mathrm{C}$. 
A small quantity $(3 \mu 1)$ of PCR product was added into wells of $1 \%$ agarose gel for electrophoresis. To indicate the base pair length, $1 \mathrm{~Kb}$ ladder in one well of the gel was added. A charge of 80 volts was passed through the gel for approximately $40-60 \mathrm{~min}$. This causes the negatively charged DNA to travel towards the positively charged electrode. After PCR all samples were sent to
Singapore for $1^{\text {st }}$ base laboratory for further purification and sequencing. Sequencing analysis was done using Codon Code Aligner and MEGA 6 software's.

\begin{tabular}{llccc}
\multicolumn{6}{l}{ Table 1 Design of Oligonucleotide primers of MSTN gene of Thalli and Pak-Karakul sheep species. } \\
\hline Exons & Oligonucleotides primers & Amplicons (bp) & $\begin{array}{l}\text { Annealing } \\
\text { temp. }\end{array}$ & $\begin{array}{l}\text { Melting } \\
\text { temp. }\end{array}$ \\
\hline Exon 1 F. & CAAGTTGTCTCTCAGACTGG & & & \\
Exon 1 R. & ACACTAGAACAGCAGTCAGC & $545 \mathrm{bp}$ & $58^{\circ} \mathrm{C}$ & $60^{\circ} \mathrm{C}$ \\
$\begin{array}{l}\text { Exon 2 F. } \\
\text { Exon 2 R. }\end{array}$ & $\begin{array}{l}\text { ATAGATTGACATGGAGGC } \\
\text { ATAAGCACAGGAAACTGG }\end{array}$ & $551 \mathrm{bp}$ & $50^{\circ} \mathrm{C}$ & $52^{\circ} \mathrm{C}$ \\
Exon 3 F. & TAATGACTCCTTGCGGTAGG & & & \\
Exon 3 R. & TACTCTAGGCTTATAGCCCG & $548 \mathrm{bp}$ & $58^{\circ} \mathrm{C}$ & $60^{\circ} \mathrm{C}$ \\
\hline
\end{tabular}

\section{RESULTS}

In an elementary phase of this research, Gradient and standard PCR were done by using the DNA extracted from the blood samples. The PCR product was run on agarose gel for visualizing the predicted size. The amplification of total DNA of blood samples yielded the PCR fragments of $545 \mathrm{bp}, 551 \mathrm{bp}$, and $548 \mathrm{bp}$ as it was expected size for Exon no 1, 2 \& 3 respectively. In exon no $1 \mathrm{G} / \mathrm{T}$ mutation was observed in three Thalli sheep and two Pak-karakul sheep samples (fig 1).

\section{Polymorphism in MSTN gene}

Ten samples of each breed were sequenced to check the polymorphisms in Thalli and Pak-karakul sheep population. Heterozygous loci were observed at the position number3995th of accession number DQ530260.1.T/G heterozygous position was observed in three Thalli sheep and at the same position G/T mutation in two Pak-Karakul sheep breed at exon 1 region while at exon 2 and 3 , no any mutation were observed. Two types of alleles were observed, mutant allele was labeled as "A" and wild type as "B" (Table 2).

\section{Calculation of Gene and Genotypic Frequency}

Gene and genotypic frequency was calculated with the help of popgene software Gene frequency of Exon no. 1 was different because mutation was observed in Thalli sheep breed. While, no mutation detected in case of Exon 2 and Exon 3. So according to Hardy Weinberg law, Gene frequency was same in case of no mutation.

\section{Calculation of MSTN gene frequency}

Exon 1 was polymorphic in Pak-karakul sheep breed; it had mutation at 3995 region of MSTN gene. The following calculations were used for MSTN gene frequency measurement.

Total no of animals of each breed 10

The formula of gene frequency is: $(\mathrm{A}+\mathrm{B})^{2}=\mathrm{A}^{2}+\mathrm{B}^{2}+2 \mathrm{AB}$

Calculated Gene frequency and expected genotypic frequency is shown in the table 3 which is calculated by Hardy Weinberg law. These results showed that heterozygosity exists in local sheep breeds of Pakistan.

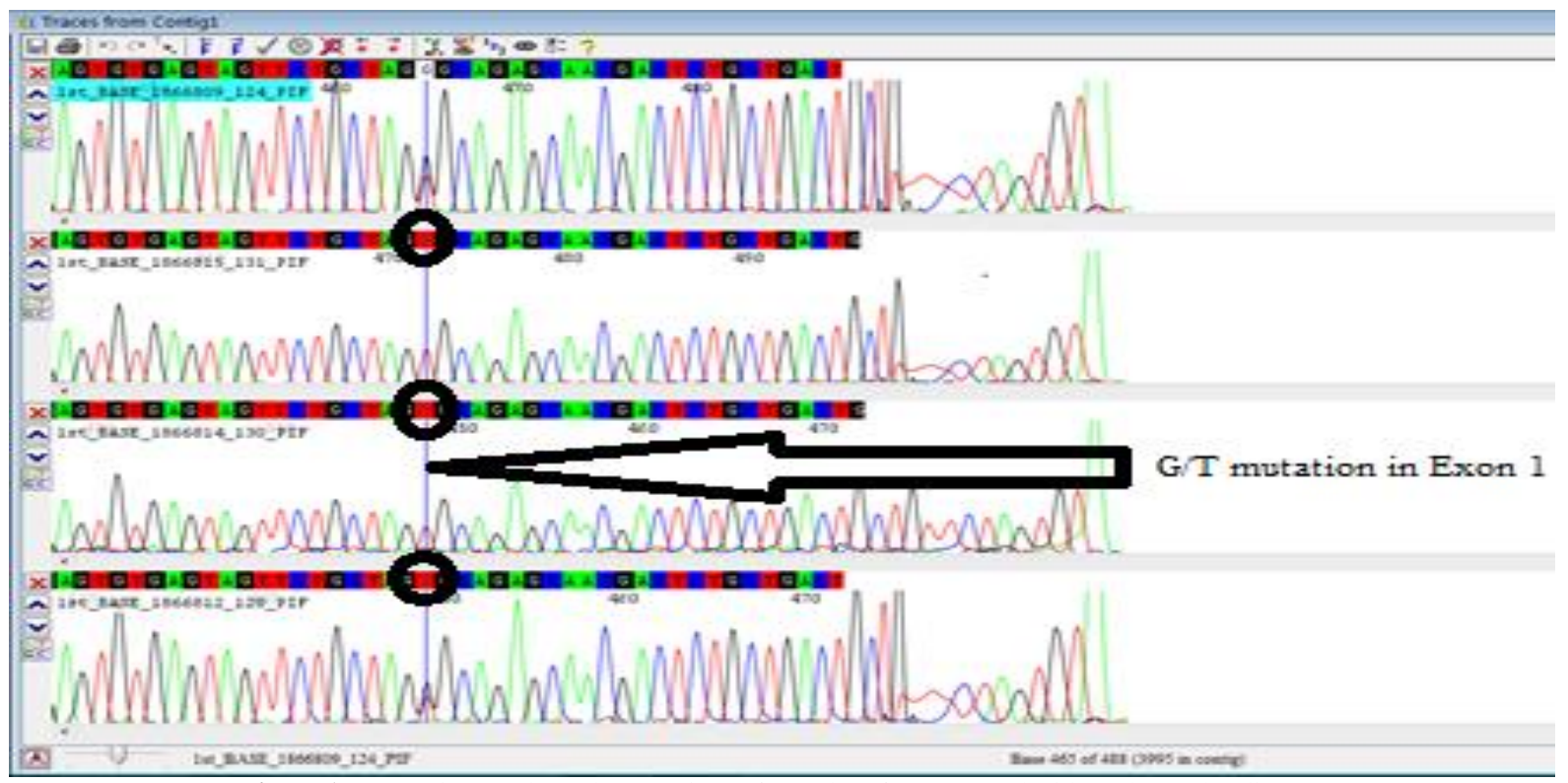

Figure 1 Sequencing results and comparison of samples of Exon 1 read with CodonCode Aligner.

Table 2 Mutations in exons in Thalli and Pak-karakul sheep breed

\begin{tabular}{|c|c|c|c|c|c|}
\hline SR.NO & Breed & Exon 1 & Mutation & Exon 2 & Exon 3 \\
\hline 1 & Thalli & $\mathrm{G} / \mathrm{T}$ & Heterozygous & $++^{*}$ & ++ \\
\hline 2 & Thalli & $\mathrm{G} / \mathrm{T}$ & Heterozygous/Synonymous & ++ & ++ \\
\hline 3 & Thalli & $\mathrm{G} / \mathrm{T}$ & Heterozygous/Synonymous & ++ & ++ \\
\hline 4 & Pak-karakul & $\mathrm{T}$ & Homozygous/Synonymous & ++ & ++ \\
\hline 5 & Pak-karakul & $\mathrm{T}$ & Homozygous/Synonymous & ++ & ++ \\
\hline
\end{tabular}

Note: where ++ shows the wild type or no mutation. 
Table 3 Gene and genotypic frequency.

\begin{tabular}{llllll}
\hline & Gene Frequency & \multicolumn{2}{c}{ Genotypic Frequency } \\
& $\mathrm{A}^{*}$ & $\mathrm{~B}^{+}$ & $\mathrm{AA}$ & $\mathrm{AB}$ & $\mathrm{BB}$ \\
\hline Pak-karakul & 0.2 & 0.8 & 0.04 & 0.32 & 0.64 \\
Thalli & 0.3 & 0.7 & 0.09 & 0.42 & 0.49 \\
\hline
\end{tabular}

* Polymorphic allele, +wild type allele

\section{DISCUSSION}

The MSTN gene encodes a protein which acts as a negative regulator for the muscular mass in mammalian species. Its role has been described for growth of muscle. Despite the undesirable effects of double muscling, the characterization of the polymorphisms that results in double muscling has created an opportunity to exploit the phenotype in livestock breeding using optimal breeding systems (Keele and Fahrenkrug, 2001). The variations in the MSTN gene have been extensively studied and reviewed in various small and large ruminants in the world (Zhou H et al., 2008), but it has never been studied in sheep breeds of Pakistan.

To better understand the distribution of genetic variation in ovine MSTN, this investigation explored diversity in 2 commercial sheep breeds from Pakistan. An extended region of the gene spanning nucleotide no. 3995 in the promoter region was analyzed. The present study was based on sequence analysis of the noncoding region of the sheep myostatin gene, four SNPs were identified in the $5^{\circ}$ promoter region, $5^{\mathrm{ce}}$-UTR and $3^{\mathrm{ce}}$-UTR and seven new reported SNPs were identified in the exons. All the SNPs were found at the position 3995 in exon no.1. The main emphasis of present research shifted to analyze the SNPs in the regulatory region (putative promoter and UTRs) because they are most likely to influence the meat traits by modulating the level of MSTN expression. Piedmontese and Belgian Blue cattle breeds have phenotypically the doubled muscular appearance with decreased bone mass, connective tissue and fat. An obviously distinct muscular hypertrophy, usually known as double muscling, occurs with high frequency in these breeds (Esmailizadeh et al., 2008). Hence, SNPs of the MSTN gene could influence the functional structure of MSTN protein and has direct impact on muscle growth (Hadjipavlou et al., 2008). It was found that two SNPs in the MSTN gene have considerable link with muscle depth of commercial Charollais sheep (Yu et al., 2007) and two SNPs in the 5 regulatory region of the MSTN gene were associated with untimely growth character in Yorkshire pigs (Esmailizadeh et al., 2008). SNP (F94L) in the MSTN gene affecting growth, reproduction and beef quality traits of Bostaurus (Kambadur et al., 1997; McPherron and Lee, 1998). The heterozygosity was observed only in Thalli sheep breed. The Thalli breed has maximum body weight but in the case of karakul breed that has high body weight the only $\mathrm{T}$ mutation was found. G/T transition was observed only in exon 1of myostatin region. So it can be concluded that heterozygous position $\mathrm{G} / \mathrm{T}$ and $\mathrm{T}$ mutations can significantly facilitate muscle growth.

\section{CONCLUSION}

It is concluded from the present study that polymorphism is present in both loca Pakistani breeds (Thalli and Pak-Karakul). The outcome of the current study may be applicable in identifying markers and designing breeding plans of both sheep breeds for enhanced mutton production through analyzing association studies at large scale.

Acknowledgments: The authors would like to thank Mr. Asad Ali, Department of Livestock Production, University of Veterinary and Animal Sciences, Lahore, Pakistan for assistance during research work.

\section{REFERENCES}

AN, X. P., WANG, J. G., HOU, J. X., ZHAO, H. B., BAI, L., LI, G., WANG, L.X., LIU, X.Q., XIAO, W.P., SONG, X.Y., CAO, B. Y. 2011. Polymorphism identification in the goat MSTN gene and association analysis with growth traits. Czech Journal of Animal Science, 56(12), 529-535.

BOMAN, I. A., KLEMETSDAL, G., BLICHFELDT, T., NAFSTAD, O., VÅGE, D. I. 2009. A frameshift mutation in the coding region of the myostatin gene (MSTN) affects carcass conformation and fatness in Norwegian White Sheep (Ovis aries). Animal genetics, 40(4), 418-422.

https://doi.org/10.1111/j.1365-2052.2009.01855.x

ESMAILIZADEH, A. K., BOTTEMA, C. D. K., SELLICK, G. S., VERBYLA, A. P., MORRIS, C. A., CULLEN, N. G., PITCHFORD, W. S. 2008. Effects of the myostatin F94L substitution on beef traits. Journal of Animal Science, 86(5), 1038-1046. https://doi.org/10.2527/jas.2007-0589

GAN, S.Q., DU, Z., LIU, S.R., YANG, Y.L., SHEN, M., WANG, X.H., YIN, J.L., HU, X.X., FEI, J., FAN, J.J., WANG, J.H. 2008. Association of SNP haplotypes at the myostatin gene with muscular hypertrophy in sheep. AsianAustralasian Journal of Animal Sciences, 21(7), pp.928-935.

HADJIPAVLOU, G., MATIKA, O., CLOP, A., BISHOP, S. C. 2008. Two single nucleotide polymorphisms in the myostatin (GDF8) gene have significant association with muscle depth of commercial Charollais sheep. Animal Genetics, 39(4), 346-353. https://doi.org/10.1111/j.1365-2052.2008.01734.x HAN, J., FORREST, R. H., SEDCOLE, J. R., HICKFORD, J. G. H. 2015 Myostatin (MSTN) gene haplotypes and their association with growth and carcass traits in New Zealand Romney lambs. Small Ruminant Research, 127, 8 19.

https://doi.org/10.1016/j.smallrumres.2015.03.015

JOULIA-EKAZA, D., CABELLO, G. 2007. The myostatin gene: physiology and pharmacological relevance. Current opinion in pharmacology, 7(3), 310-315. https://doi.org/10.1016/j.coph.2006.11.011

KEELE, J. W., FAHRENKRUG, S. C. 2001. Optimum mating systems for the myostatin locus in cattle. Journal of animal science, 79(8), 2016-2022. https://doi.org/10.2527/2001.7982016x

MCPHERRON, A. C., LEE, S. J. 1997. Double muscling in cattle due to mutations in the myostatin gene. Proceedings of the National Academy of Sciences, 94(23), 12457-12461.

https://doi.org/10.1073/pnas.94.23.12457

NOELLE E.C., A.S. MARIA, A.B. CHRISTOPHER, S. KARIN, L.H. TRACY D.S. GARY DS, G. MICHEL., CAROLE, C. 2005. The callipyge mutation and other genes that affect muscle hypertrophy in sheep. Genet SelEvol, 37 (1), 65 81.

https://doi.org/10.1186/1297-9686-37-S1-S65

SAMBROOK J., FRITSCH E.F.., MINIATIS, T. 1989. Molecular cloning: A laboratory manual. 2nd ed. Cold Spring Harbor Laboratory Press, New York.

TAY, G. K., IASCHI, S. P. A., BELLINGE, R. H. S., CHONG, F. N., HUI, J 2004. The development of sequence-based-typing of myostatin (GDF-8) to identify the double muscling phenotype in the goat. Small Ruminant Research, 52(1-2), 1-12

https://doi.org/10.1016/S0921-4488(03)00248-7

WANG, G. F., WU, D. J. (2006). Correlation analysis of microsatellite DNA markers with wool traits in Liangshan semi-fine wool sheep. Yi chuan= Hereditas, 28(12), 1505-1512.

https://doi.org/10.1360/yc-006-1505

WHITTEMORE, L.A., SONG, K., LI, X., AGHAJANIAN, J., DAVIES, M., GIRGENRATH, S., HILL, J.J., JALENAK, M., KELLEY, P., KNIGHT, A. MAYLOR, R. 2003. Inhibition of myostatin in adult mice increases skeletal muscle mass and strength. Biochemical and biophysical research communications, 300(4), pp.965-971.

https://doi.org/10.1016/S0006-291X(02)02953-4

YU, L., TANG, H., WANG, J., WU, Y., ZOU, L., JIANG, Y., WU, C., LI, N 2007. Polymorphisms in the 5 ' regulatory region of myostatin gene are associated with early growth traits in Yorkshire pigs. Science in China Series C: Life Sciences, 50(5), pp.642-647.

https://doi.org/10.1007/s11427-007-0075-4

ZHANG, C., LIU, Y., XU, D., WEN, Q., LI, X., ZHANG, W., YANG, L. 2012 Polymorphisms of myostatin gene (MSTN) in four goat breeds and their effects on Boer goat growth performance. Molecular biology reports, 39(3), 3081-3087. https://doi.org/10.1007/s11033-011-1071-0

ZHOU, H., HICKFORD, J. G., FANG, Q. 2008. Variation in the coding region of the myostatin (GDF8) gene in sheep. Molecular and cellular probes, 22(1), 67-68.

https://doi.org/10.1016/j.mcp.2007.08.004 